
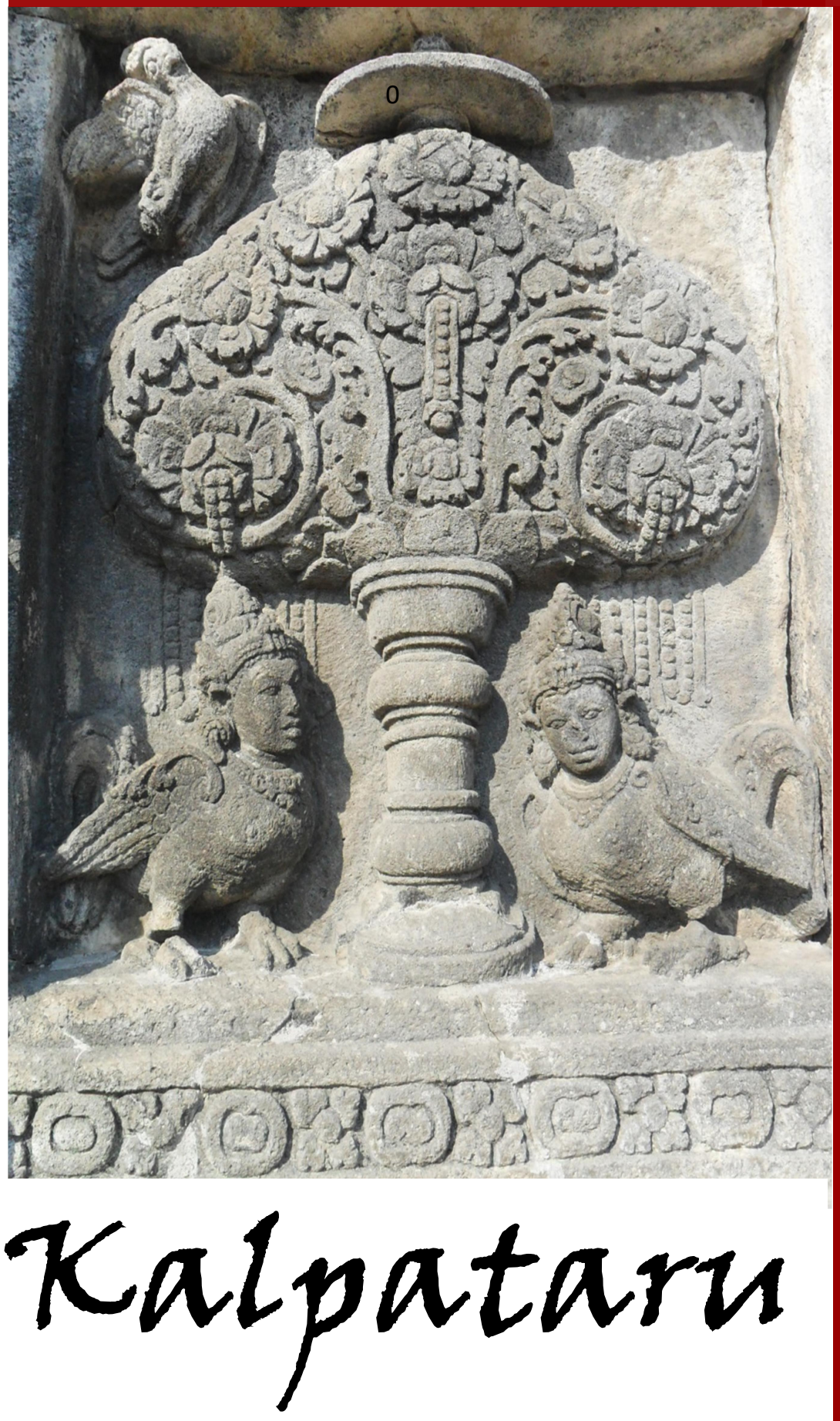

\author{
JURNAL SEJARAH DAN \\ PEMBELAJARAN SEJARAH
}

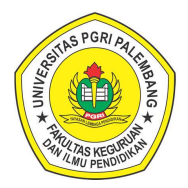

Program Studi Pendidikan Sejarah Jurusan Pendidikan IPS

Fakultas Keguruan dan IImu Pendidikan Universitas Persatuan Guru Republik Indonesia Palembang
Pengaruh Model Pembelajaran Student Facilitator and Explaining Terhadap Hasil Belajar Siswa Pada Mata Pelajaran Sejarah Kelas $X$ di SMA Negeri 3 Palembang

Sarinah, Nur Ahyani, Ahmad Zamhari

Pengaruh Model Pembelajaran Berbasis Masalah (PBM) Terhadap Hasil Belajar Siswa Pada Mata Pelajaran IPS Terpadu (Sejarah) Kelas VIII di SMP Negeri 2 Palembang

Neka Dapistri, Nur Ahyani, Ahmad Zamhari

Penerapan Media Pembelajaran Menggunakan Google Earth Dalam Materi Kondisi Masyarakat Indonesia Pada Masa Penjajahan Terhadap Hasil Belajar Siswa Pada Mata Pelajaran IPS Terpadu di SMP Quraniah Palembang

Tri Nur Ariani, Eva Dina Chairunisa, Ida Suryani

Perkembangan Sosial Budaya Suku Jawa di Desa Kapasan Tegalrejo BK $X$ Kecamatan Belitang Kabupaten Ogan Komering Ulu Timur Sebagai Sumber Pembelajaran Sejarah di SMA Muhammadiyah 2 Karang Tengah

Ratna Puspita Dewi, Sukardi, Mirza Fansyuri

Pengembangan E-Modul Pembelajaran Sejarah Tokoh-Tokoh Pembangunan

Susi Susanti, Eva Dina Chairunisa

Peran Pendidikan Sejarah Dalam Membentuk Karakter Bangsa

Sukardi, Jeki Sepriady

Sejarah Pengajaran Mantra Melayu di Tengah Perubahan Masyarakat Besemah Muhamad Idris, Eva Dina Chairunisa, Jeki Sepriady

Pengembangan Media Audio Visual Sejarah Kolonialisme Barat di Indonesia Materi Benteng Marlborough Bengkulu Hamza Kurniawan 


\section{Kalpataru}

Jurnal Sejarah dan Pembelajaran Sejarah

Volume 6, Nomor 2, Desember 2020

\section{Chief Editor}

Drs. Sukardi, M.Pd.

\section{Editor}

Dr. Muhamad Idris, M.Pd.

Eva Dina Chairunisa, M.Pd.

Jeki Sepriady, S.Pd.

\begin{tabular}{ll}
\multicolumn{2}{c}{ Reviewer } \\
Dr. Tahrun, M.Pd. & (Universitas PGRI Palembang) \\
Drs. Supriyanto, M.Hum. & (Universitas Sriwijaya Palembang) \\
Dra. Retno Purwati, M.Hum. & (Balai Arkeologi Sumatera Selatan) \\
Dr. Nor Huda Ali, M.Ag., M.A. & (Masyarakat Sejarawan Indonesia Sumsel) \\
Dr. Budi Agung Sudarman, S.S., M.Pd. & (Balai Bahasa Provinsi Sumatera Selatan) \\
Dr. Purmansyah, M.A. & (Universitas Muhammadiyah Palembang)
\end{tabular}

Alamat Redaksi

Program Studi Pendidikan Sejarah

Fakultas Keguruan dan IImu Pendidikan Universitas PGRI Palembang

Telp. 0711-510043

Email: jurnalkalpatarusejarah@gmail.com

Website: https://jurnal.univpgri-palembang.ac.id/index.php/Kalpa 


\section{Kalpataru}

JURNAL SEJARAH DAN

PEMBELAJARAN SEJARAH

Terbit dua kali setahun pada Juli dan Desember

Diterbitkan oleh:

Program Studi Pendidikan Sejarah

Jurusan Pendidikan IPS

Fakultas Keguruan

dan IImu Pendidikan

Universitas PGRI Palembang

\section{Gambar Cover:}

Pohon Kalpataru

Candi Prambanan

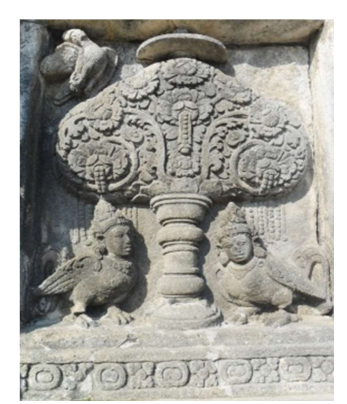

Koleksi: Muhamad Idris 


\section{DAFTAR ISI}

Pengaruh Model Pembelajaran Student Facilitator and Explaining Terhadap Hasil Belajar Siswa Pada Mata Pelajaran Sejarah Kelas X di SMA Negeri 3 Palembang

Sarinah, Nur Ahyani, Ahmad Zamhari 83-89

Pengaruh Model Pembelajaran Berbasis Masalah (PBM) Terhadap Hasil Belajar Siswa Pada Mata Pelajaran IPS Terpadu (Sejarah) Kelas VIII di SMP Negeri 2 Palembang

Neka Dapistri, Nur Ahyani, Ahmad Zamhari..... 90-95

Penerapan Media Pembelajaran Menggunakan Google Earth Dalam Materi Kondisi Masyarakat Indonesia Pada Masa Penjajahan Terhadap Hasil Belajar Siswa Pada Mata Pelajaran IPS Terpadu di SMP Quraniah Palembang

Tri Nur Ariani, Eva Dina Chairunisa, Ida Suryani $96-101$

Perkembangan Sosial Budaya Suku Jawa di Desa Kapasan Tegalrejo BK X Kecamatan Belitang Kabupaten Ogan Komering Ulu Timur Sebagai Sumber Pembelajaran Sejarah di SMA Muhammadiyah 2 Karang Tengah

Ratna Puspita Dewi, Sukardi, Mirza Fansyuri. $102-109$

Pengembangan E-Modul Pembelajaran Sejarah Tokoh-Tokoh Pembangunan Pacsa Kemerdekaan di Sumatera Selatan

Susi Susanti, Eva Dina Chairunisa 110-113

Peran Pendidikan Sejarah Dalam Membentuk Karakter Bangsa

Sukardi, Jeki Sepriady $114-117$

Sejarah Pengajaran Mantra Melayu di Tengah Perubahan Masyarakat Besemah Muhamad Idris, Eva Dina Chairunisa, Jeki Sepriady..... 118-127

Pengembangan Media Audio Visual Sejarah Kolonialisme Barat di Indonesia Materi Benteng Marlborough Bengkulu

Hamza Kurniawan. 128-135 
Kalpataru, Volume 6, Nomor 2, Desember 2020 (90-95)

\title{
PENGARUH MODEL PEMBELAJARAN BERBASIS MASALAH (PBM) TERHADAP HASIL BELAJAR SISWA PADA MATA PELAJARAN IPS TERPADU (SEJARAH) KELAS VIII DI SMP NEGERI 2 PALEMBANG
}

\author{
Neka Dapistri \\ Mahasiswa Program Studi Pendidikan Sejarah, FKIP Universitas PGRI Palembang \\ Email: ndapistri@gmail.com \\ Nur Ahyani \\ Dosen Program Studi Pendidikan Sejarah, FKIP Universitas PGRI Palembang \\ Email: nurahyani_sj@univpgri-palembang.ac.id \\ Ahmad Zamhari \\ Dosen Program Studi Pendidikan Sejarah, FKIP Universitas PGRI Palembang \\ Email: ahmadzamhari_sj@univpgri-palembang.ac.id
}

\begin{abstract}
ABSTRAK
Model pembelajaran berfungsi sebagai media transportasi pembelajaran terhadap tujuan yang ingin dicapai. Model dan alat pembelajaran yang digunakan harus benar-benar efektif sesuai materi yang di sampaikan demi mencapai tujuan pembelajaran. Diharapkan dengan adanya model pembelajaran agar dapat meningkatkan hasil belajar siswa serta keefektifan belajar siswa lebih optimal dan memberikan kemudahan untuk mamahami materi yang diajarkan. Tujuan penelitian ini untuk mengetahui pengaruh model pembelajaran berbasis masalah (PBM) terhadap hasil belajar siswa pada mata pelajaran IPS Terpadu (Sejarah) di kelas VIII SMP Negeri 2 Palembang. Dalam penelitian ini menjadi populasi adalah kelas VIII di SMP Negeri 2 Palembang yang berjumlah 337 yang terbagi menjadi 9 kelas. Adapun teknik pengambilan sampel yaitu dengan cara random sampling yang menjadi kelas eksperimen adalah kelas VIII.1 dan yang menjadi kelas kontrol VIII.2. Metode yang digunakan adalah hasil tes. Tes digunakan untuk mengumpulkan data mengenai hasil belajar siswa pada model pembelajaran berbasis masalah (PBM). Ada beberapa teknik analisa data yang digunakan untuk membuktikan hipotesis adalah uji-t di peroleh nilai $t$. Hasil analisis uji-t diproleh nilai $t_{\text {hit }}$ yang lebih besar dari pada nilai $t_{\text {tabel }}$ dimana nilai $t_{\text {hitung }}=550,251$ dan $t_{\text {tabel }}=1,67022$ dapat diyatakan bahwa $t_{\text {hitung }}=550,251>t_{\text {tabel }}=1,67022$ Maka $H_{o}$ ditolak dan $H_{a}$ diterima.
\end{abstract}

Kata Kunci: Model Pembelajaran Berbasis Masalah (PBM), Hasil Belajar.

\section{A. PENDAHULUAN}

Pendidikan merupakan sarana yang kompleks, dan meliputi berbagai komponen yang berkaitan erat satu sama lain. Oleh sebab itu, apabila pendidikan ingin dilaksanakan secara terencana dan teratur, maka berbagai faktor yang dilibatkan dalam pendidikan harus dipahami terlebih dahulu. Berbagai komponen dalam sistem pendidikan, baik secara mikro maupun dalam kajian makro perlu dikenal secara mendalam sehingga komponenkomponen tersebut dapat difungsikan dan dikembangkan guna mengoptimalkan gerapan pendidikan tersebut kearah pencapaian tujuan pendidikan yang ditetapkan.
Pendidikan merupakan salah satu bentuk perwujudan kebudayaan manusia yang dinamis dan sarat perkembangan. Oleh karena itu, perubahan atau perkembangan. Oleh karena itu, perubahan atau perkembangan pendidikan adalah hal yang memang harusnya terjadi sejalan dengan perubahan budaya kehidupan. Perubahan dalam arti perbaikan pendidikan pada semua tingkat perlu terusmenerus dilakukan sebagai antisipasi kepentingan masa depan (Trianto, 2009:1).

Belajar merupakan suatu proses yang dilakukan oleh seseorang untuk memperoleh suatu perubahan yang baru sebagai hasil dan pegalaman secara interasi dengan lingkungan (Sutikno, 2010:5). 


\section{Kalpataru, Volume 6, Nomor 2, Desember 2020 (90-95)}

Menurut Slameto (2010:2), belajar adalah suatu proses usaha yang dilakukan seseorang untuk memperoleh perubahan tingkah laku yang baru secara keseluruhan, sebagai hasil pegalamannya sendiri dalam interaksi dengan lingkungannya," perubahan sebagai hasil dari proses belajar ditunjukan dalam berbagai bentuk seperti perubahan sikap dan tingkah laku, pengetahuan keterampilan kebiasaan, serta perubahanperubahan pada aspek yang ada pada diri siswa.

IImu Pengetahuan Sosial (IPS) merupakan salah satu bidang studi yang mempelajari, menelaah, menganalisis gejala sosial di masyarakat dengan meninjau dari berbagai aspek kehidupan. Stopsky dan Sharon menyatakan bahwa masyarakat laboratoriumnya IPS. Karena setiap kegiatan pembelajara IPS mampu menyediakan realitas masyarakat lingkungan siswa dalam hidup keseharianya. Kemajuan ilmu teknologi telah membawa dampak pada penurunan nilai-nilai kebangsaan dan nasionalisme di berbagai belahan dunia. Hal yang membuktikan dari IPS adalah mata pelajaran yang berisikan fakta, dan pristiwa masa lalu.

Hasil belajar menurut Gagne \& Briggs adalah kemampuan-kemampuan yang dimiliki siswa sebagai akibat perbuatan belajar dan dapat diamati melalui penampilan siswa (learner"s performance). Dalam dunia pendidikan, terdapat bermacam-macam tipe hasil belajar yang telah dikemukakan oleh para ahli antara lain Gagne, mengemukakan lima tipe dari hasil belajar, yaitu intellectual skill, cognitive strategy, verbal information, motor skill, dan attitude (Jamil, 2012:37).

Sardiman dalam Jamil (2012:38), menyatakan dengan mengetahui hasil pekerjaan, apalagi kalau terjadi kemajuan, akan mendorong siswa untuk lebih giat belajar. Semakin mengetahui bahwa grafik hasil belajar meningkatkan maka ada motivasi pada diri siswa untuk terus belajar, dengan suatu harapan hasilnya terus meningkat.

Pembelajaran Berbasis Masalah, guru dituntut dapat memilih model pembelajaran yang dapat memacu semangat siswa untuk secara aktif ikut terlibat dalam pengalaman belajarnya. Salah satu alternatif model pembelajaran yang memungkinkan dikembangkannya cara berpikir siswa (peranan, komunikasi, dan koneksi) dalam memecahkan masalah adalah pembelajaran berbasis masalah (PBM) (Rusman, 2010: 229).

Model pembelajaran adalah kerangka konseptual yang menggambarkan prosedur sistematik (teratur) dalam pengorganisasian kegiatan (pengalaman) belajar untuk mencapai tujuan belajar (kompetensi belajar). Dengan kata lain, model pembelajaran adalah rancangan kegiatan belajar agar pelaksanaan KBM dapat berjalan dengan baik, menarik, mudah dipahami, dan sesuai dengan urutan yang logis.

Menurut Khabibah (2006:25), bahwa untuk melihat tingkat kelayakan suatu model pembelajaran untuk aspek validitas dibutuhkan ahli dan praktisi untuk memvalidasi model pembelajaran yang dikembangkan. Sedangkan untuk aspek kepraktisan dan efektivitas diperlakukan suatu perangkat pembelajaran untuk melaksanakan model pembelajaran yang dikembangkan. Sehinggab untuk melihat kedua aspek ini perlu dikembangkan suatu perangakat pembelajaran untuk suatu topik tertentu yang sesuai dengan model pembelajaran yang dikembangkan pula instrumen penelitian yang sesuai dengan tujuan yang diinginkan (Trianto, 2009:25).

Kelebihan model Pembelajaran Berbasis Masalah adalah: 1) Meberikan tantangan kepada siswa untuk menemukan pengetahuan baru bagi siswa; 2) Membantu siswa bagaimana mentransfer pengetahuan mereka untuk memahami masalah dalam kehidupan nyata; 3) Mengembangkan kemampuan siswa untuk berpikir kritis; 4) Siswa didorong untuk memiliki kemampuan memecahkan masalah dalam situasi nyata; 5) Siswa memiliki kemampuan membangun pengetahuannya sendiri melalui aktivitas belajar; 6) Pembelajaran berfokus pada masalah sehingga materi yang tidak ada hubungan tidak perlu saat inti dipelajari oleh siswa. Hal ini menguranggi beban mengharap atau menyimpan informasi; 7) Terjadi aktivitas ilmiah pada siswa melalui kerja kelompok; 8) Siswa terbiasa mengunakan sumber-sumber 


\section{Kalpataru, Volume 6, Nomor 2, Desember 2020 (90-95)}

pengetahuan baik dari perpustakaan , internet, wawancara, dan observasi; 9) Siswa memiliki kemampuan menilai kemajuan belajarnya sendiri; 10) Siswa memiliki kemampuan untuk untuk melakukan komunikasi ilmiah dalam kegiatan diskusi atau persentasi hasil perkerjaan mereka; 11) Kesulitan Siswa serta individual dapat diatasi melalui kerja kelompok dalam bentuk peer teaching.

Kelemahan model Pembelajaran Berbasis Masalah adalah: 1) Manakalah siswa tidak memiliki minat atau tidak mempunyai kepercayaan bahwa masalah yang dipelajari sulit untuk dipecahkan, maka mereka akan merasa enggan untuk mencobanya; 2) Membutuhkan cukup waktu untuk persiapan pembelajaran; 3) PBM tidak dapat diterapkan untuk setiap materi pelajaran, ada bagian guru berperan aktif dalam menyajikan materi. PBM lebih cocok untuk pembelajaran yang menuntut kemampuan tertentu yang kaitan pemecahan masalah; 4) Dalam satu kelas yang memiliki tingkat keragaman siswa yang tinggi akan terjadi kesulitan dalam pembagian tugas. PBM kurang cocok untuk diterapkan di sekolah dasar karena memampuan bekerja dalam kelompok. PBM sangat cocok perguruan tinggi atau paling tidak sekolah menegah; 4) PBM biasanya membutuhkan waktu yang tidak sedikit sehingga dikhawatirkan tidak dapat menjangkau seluruh konten yang diharapkan; 5) Membutuhkan kemampuan guru yang mampu mendorong kinerja siswa motivasi siswa dengan baik; 6) Adakalanya sumber yang dibutuhkan tidak tersedia dengan lengkap.

Dalam penelitian ini rumusan masalah penelitian ini ialah: adakah pengaruh model Pembelajaran Berbasis Masalah (PBM) terhadap hasil belajar siswa pada mata pelajaran IPS Terpadu (Sejarah) di kelas VIII SMP Negeri 2 Palembang.

\section{B. METODE PENELITIAN \\ 1. Variabel Penelitian}

Variabel dalam materi dengan kutipan atau penelitian ini ialah model pembelajaran berbabasis masalah, hasil belajar. Penelitian ini menguji hubungan dua variabel yaitu:
X (Variabel Bebas): Model Pembelajaran Berbasis Masalah.

Y (Variabel terikat): Hasil Belajar Siswa.

\section{Tempat dan Waktu Penelitian}

Penelitian ini dilakukan di SMP Negeri 2 Palembang dan waktu penelitian dilakukan pada bulan Juni sampai Juli 2020.

\section{Populasi Penelitian}

Menurut Sugiyono (2015:117) populasi adalah wilayah generalisasi yang terdiri atas obyek/subyek yang merupakan kualitas atau karakteristik tertentu yang ditetepkan oleh peneliti untuk di pelajari dan ditarik kesimpulan. Adapun yang menjadi populasi dalam penilitian ini siswa kelas VIII SMP Negeri 2 Palembang dengan jumlah 9 kelas terdiri dari kelas VIII.1 sampai kelas VIII.9, dengan jumlah keseluruhan siswa 337 yang di jadikan sebagai populasi.

\section{Sampel Penelitian}

Menurut Arikunto (2002:117), sampel adalah sebagian dari populasi yang diteliti. Besarnya sampel yang akan diambil tergantung pada jumlah subjek dalam populasi. Apabila subjek penelitiannya kurang dari 100, lebih baik diambil semuanya sehingga penelitiannya merupakan penelitian populasi. Jika jumlah sampel lebih besar maka diambil antara $10-15 \%$ atau lebih. Penelitian pada model pembelajaran berbasis masalah terhadap hasil belajar siswa pada mata pelajaran IPS terpadu (Sejarah) kelas VIII di SMP Negeri 2 Palembang.

Dalam motode pengambilan sampel penelitian ini menggunakan teknik random sampling atau disebut dengan cara acak. Dalam hal ini yang diambil kelas eksperimen dan kelas kontrol sebagai perbandingan.eksperimen dengan perlakuan menggunakan model pembelajaran berbasis masalah dan kelas kontrol kelas yang tidak menggunakan model pembelajaran. Maka kelas yang digunakan sample adalah kelas VIII.1 33 siswa kelas ekspiremen dan kelas VIII.2 32 siswa kelas kontrol, dengan jumlah sebanyak 65 siswa yang diambil sebagai sampel. 


\section{Kalpataru, Volume 6, Nomor 2, Desember 2020 (90-95)}

\section{Teknik Pengumpulan Data}

Teknik pengumpulan data ini digunakan observasi, catatan lapangan dan tes hasil belaja. Data yang diolah dalam penelitian ini merupakan data pelaksaan dan data hasil belajar siswa data pelaksaan tindakan kelas yang di maksud merupakan proses pengaruh model pembelajaran berbasis masalah. Sedangkan hasil belajar siswa adalah penitian ini diperole dari penelitian aktivitas kegiatan belajar siswa berupa hasil belajar siswa.

\section{Teknik Analisis Data}

Analis data merupakan langkah paling awal dalam penelitian karena teknik analisis data berfungsi untuk meyimpulkan hasil penelitian.Tahap pertama reduksi data, dimulai dengan melihat dan menganalisis data dan observasi, dan hasil tes. Kemudian melakukan reduksi data dengan cara merangkum hal yang penting yang dijadikan dalam pokus penelitian yang dilakukan hasil observasi, dan tes dan kemudian data reduktif disusun dan digolongkan berdasarkan kinerja guru dan aktivitas siswa. Tahap kedua peyajian data, diilakukan dengan peyajian data dalam bentuk lebih sederhana yaitu dalam bentuk paparan naratif, dan tabel. Kesimpulan dengan cara pengambilan inti peyajian secara singkat dan padat sehingga dapat menjawab rumusan masalah yang telah di buat.

\section{Kriteria Penguji Hipotensis}

Menurut Sugiyono (2015:296), mengemukakan bahwa hipotensis adalah dugaan atau pertayaan sementara yang diungkapkan secara secara deklaratif sementara yang menjadi jawaban dari sebuah permasalahan:

\section{Uji t (Secara Parsial)}

Menurut Syamsudin varians gabungan rata-rata hitung dan selisih rata-rata hitung populasi.

$$
\begin{aligned}
& s^{1} \mathrm{p}=\frac{(n-1)\left(s_{1}^{2}\right)+(n,-1)\left(s_{2}^{2}\right)}{\left(n_{1}+n_{2}\right)-2} \\
& \mathrm{t}=\frac{x_{1-x_{2}}}{\sqrt{s^{1\left[\frac{1}{n_{1}}+\frac{1}{n_{1}}\right]}}}
\end{aligned}
$$

Keterangan: $\mathrm{t} \quad$ : Nilai distribusi t

$x_{1} \quad$ : Nilai rata-rata sampel pertama

$x_{2} \quad$ : Nilai rata- rata sampel kedua

$s^{2} p \quad$ : Penduga varians gabungan populasi

$n_{1} \quad$ : Jumlah sampel populasi pertama

$n_{2} \quad$ : Jumlah sampel populasi kedua

$s_{1}^{2} \quad$ : Varians sampel pertama

$s_{2}^{2} \quad$ : Varians sampel kedua

Kriteria Pengujian Hipotesis

Ho: Tidak ada pengaruh model pembelajaran berbasis masalah (PBM) terhadap hasil belajar siswa pada mata pelajaran IPS terpadu (Sejarah) di kelas VIII di SMP Negeri 2 Palembang.

$\mathrm{Ha}$ : Ada pengaruh model pembelajaran berbasis masalah (PBM) terhadap hasil belajar siswa pada mata pelajaran IPS terpadu (Sejarah) kelas VIII SMP Negeri 2 Palembang.

Untuk pengujian hipotesis di atas dalam penelitian ini dipergunakan $\mathrm{Ho}$ dan $\mathrm{Ha}$.

\section{c. HASIL DAN PEMBAHASAN}

1. Hasil Penelitian

Untuk mengetahui hasil belajar siswa maka diberikan soal tes pada kelas eksperimen. Dari soal tes inilah dapat diketahui deskripsi data hasil belajar siswa yang diajarkan mengunakan strategi pengaruh model pembelajaran berbasis masalah (PBM) terhadap hasil belajar siswa pada kelas eksperimen.

Dalam penelitian ini siswa siswa yang menjadi kelas kelas sampel adalah siswa kelas VIII.1 yang berjumlah 33 siswa.Tes ini yang diberikan berupa tes dengan bentuk tema karangan yang berjumlah 10 soal. Tes ini di ajarkan mengunakan strategi pembelajaran IPS terpadu. Adapun untuk mengetahui uji kenormalan data pada kelas eksperiment dapat dilihat pada analisis sebagai berikut.

Berdasarkan analisis data hasil tes akhir kelas eksperimen yang menggunakan strategi pembelajaran IPS Terpadu, dapat diketahui bahwa nilai tertingnya adalah 88 yang didapat oleh 4 orang siswa dan nilai terendah adalah 65 yang di dapat oleh 6 orang siswa dan kelas kontrol nilai terbesar 81 yang didapat 7 Orang siswa dan nilai terendah 55 yang didapat oleh 
Kalpataru, Volume 6, Nomor 2, Desember 2020 (90-95)

3 orang siswa. Sedangkan penilaian tes latihan pada kelas eksperimen yang menggunakan model pembelajaran berbasis masalah dalam pelajaran asean dapat diketahui bahwa nilai tertinginya adalah 80 yang didapat oleh 4 orang siswa dan nilai terendahnya adalah 65 yang di dapat oleh 6 orang siswa dengan hasil tes latihan dan tes akhir.

Tabel 1

Distribusi Frekuensi Nilai Tes Akhir Kelas Ekspirimen

\begin{tabular}{|c|c|c|c|c|c|}
\hline $\begin{array}{c}\text { Interval } \\
\text { Nilai Tes }\end{array}$ & $\boldsymbol{f}_{\boldsymbol{I}}$ & $\boldsymbol{x}_{\boldsymbol{i}}$ & $\boldsymbol{f}_{\boldsymbol{i}} \boldsymbol{X}_{\boldsymbol{i}}$ & $\boldsymbol{x}_{\boldsymbol{i}}^{\mathbf{2}}$ & $\boldsymbol{f}_{\boldsymbol{i} \boldsymbol{X}_{\boldsymbol{i}}^{\mathbf{2}}}$ \\
\hline $\mathbf{5 5 - 5 7}$ & 3 & 56 & 168 & 3136 & 9408 \\
\hline $\mathbf{5 8 - 6 0}$ & 2 & 59 & 118 & 3481 & 6962 \\
\hline $\mathbf{6 1 - 6 3}$ & 0 & 62 & 0 & 3844 & 0 \\
\hline $\mathbf{6 4} \mathbf{- 6 6}$ & 3 & 65 & 195 & 4225 & 12675 \\
\hline $\mathbf{6 7 - 6 9}$ & 0 & 68 & 0 & 4624 & 0 \\
\hline $\mathbf{7 0 - 7 2}$ & 8 & 71 & 568 & 5041 & 40328 \\
\hline $\mathbf{7 3 - 7 5}$ & 4 & 74 & 296 & 5476 & 21904 \\
\hline $\mathbf{7 6 - 7 8}$ & 4 & 77 & 308 & 5929 & 23716 \\
\hline $\mathbf{7 9} \mathbf{- 8 1}$ & 8 & 80 & 640 & 6400 & 51200 \\
\hline Jumlah & 32 & 612 & 2293 & 42156 & 166193 \\
\hline
\end{tabular}

Tabel 2

Distribusi Frekuensi Nilai Tes Akhir Kelas Kontrol

\begin{tabular}{|c|c|c|c|c|c|}
\hline $\begin{array}{c}\text { Interval } \\
\text { Nilai Tes }\end{array}$ & $\boldsymbol{f}_{\boldsymbol{I}}$ & $\boldsymbol{x}_{\boldsymbol{i}}$ & $\boldsymbol{f}_{\boldsymbol{i}} \boldsymbol{X}_{\boldsymbol{i}}$ & $\boldsymbol{x}_{\boldsymbol{i}}^{\mathbf{2}}$ & $\boldsymbol{f}_{\boldsymbol{i} \boldsymbol{X}_{\boldsymbol{i}}^{\mathbf{i}}}$ \\
\hline $\mathbf{5 5 - 5 7}$ & 3 & 56 & 168 & 3136 & 9408 \\
\hline $\mathbf{5 8 - 6 0}$ & 2 & 59 & 118 & 3481 & 6962 \\
\hline $\mathbf{6 1 - 6 3}$ & 0 & 62 & 0 & 3844 & 0 \\
\hline $\mathbf{6 4} \mathbf{- 6 6}$ & 3 & 65 & 195 & 4225 & 12675 \\
\hline $\mathbf{6 7 - 6 9}$ & 0 & 68 & 0 & 4624 & 0 \\
\hline $\mathbf{7 0 - 7 2}$ & 8 & 71 & 568 & 5041 & 40328 \\
\hline $\mathbf{7 3 - 7 5}$ & 4 & 74 & 296 & 5476 & 21904 \\
\hline $\mathbf{7 6 - 7 8}$ & 4 & 77 & 308 & 5929 & 23716 \\
\hline
\end{tabular}

Uji Hipotesis

Untuk Menguji hipotesis data digunakan uji $t$ (uji pihak kanan) dengan signifikan $\mathrm{t}=\frac{x_{1-x_{2}}}{\sqrt{s^{1}\left[\frac{1}{n_{1}}+\frac{1}{n_{1}}\right]}}$

$$
\begin{aligned}
s^{1} \mathrm{p} & =\frac{(n-1)\left(s_{1}^{2}\right)+(n,-1)\left(s_{2}^{2}\right)}{\left(n_{1}+n_{2}\right)-2} \\
s^{1} \mathrm{p} & \frac{(33-1)(8,37)^{2}+(32-1)(77,98)^{2}}{(33-1)+(32-1)} \\
= & \frac{(32)(7005,69)+(31)(6080,8804)}{(32)+(31)} \\
& =\frac{224182,08+188507,2924}{63} \\
& =\frac{1907491,132}{63} \\
& =\sqrt{30277637,0159} \\
& =550,251 \\
t_{\text {tabel }=d k=}=n 1+n 2-2 & =33+32-2 \\
& =63-2 \\
& =61
\end{aligned}
$$

Berdasarkan hasil pengujian dengan menggunakan rumus uji-t di atas maka didapat hasil nilai $t_{\text {tabel }}$ untuk $\mathrm{dk}=61$ diperoleh nilai $t_{\text {tabel }}$ sebesar 1,67022 dengan menggunakan dasar taraf signifikan 0,5 jadi $t_{\text {tabel }} \geq$ $t_{\text {tabel }}$ sehingga $H_{o}$ ditolak dan $H_{a}$ diterima yang artinya "ada pengaruh yang signifikasi dari pengaruh model pembelajaran berbasis masalah (PBM terhadap hasil belajar siswa kelas VIII SMP Negeri 2 Palembang.

2.

Pemba

hasan

Penelitian ini ialah pengaruh model pembelajaran berbasis masalah (PBM) terhadap hasil belajar siswa pada mata pelajaran IPS Terpadu (Sejarah) kelas VIII di SMP Negari 2 Palembang terhadap kemampuan. Pengambilan sampel dalam penelitian ini menggunakan teknik random sampling, dalam pengambilan acak sederhana (simple random sampling), yaitu teknik pengambilan sampel yang memberikan peluang yang sama bagi setiap unsur (anggota) populasi untuk dipilih menjadi anggota sampel. Dalam penelitian ini menggunakan dua kelas sampel yaitu kelas VIII.1 sebagai kelas eksprimen yang berjumlah 33 orang siswa dan kelas VIII.2 sebagai kelas kontrol yang berjumlah 32 orang siswa.

Berdasarkan data hasil penelitian yang dilakuakn penelitian dari pertemuan pertama sampai pertemuan terakhir, dari hasil nilai ratarata tes akhir tersebut yaitu kelas eksperimen 


\section{Kalpataru, Volume 6, Nomor 2, Desember 2020 (90-95)}

yaitu 4 siswa yang mendapatkan nilai tertinggi adalah 88 yang didapatkan beberapa orang siswa dan nilai terendah 65 yang didapat oleh 6 orang siswa. Sedangkan kelas kontrol nilai tertinggi 81 yang didapat oleh 6 orang siswa dan nilai terendahnya adalah 55 yang didapat oleh 3 orang siswa. Sedangkan pada tes awal nilai tertinggi 3 siswa didapatkan oleh beberapa orang dan nilai terendah 5 siswa adalah beberapa orang. Jadi terbukti pengunaan strategi pengaruh model pembelajaran berbasis masalah (PBM) dapat meningkatkan hasil belajar siswa.

Kemudian melalui pembelajaran megunakan stategi pengaruh model pembelajaran berbasis masalah (PBM), terhadap materi pembelajaran kelas VIII dikategorikan baik. Hal ini dapat dilihat dari perolehan dan mengenai nilai hasil belajar siswa sebelum dan sesudah mendapatkan pembelajaran menggunakan stategi pengaruh model pembelajaran berbasis masalah (PBM) penelitian ini melihat adanya peningkatan hasil belajar siswa setiap kali pertemuan pembelajaran yang dilihat dari perolehan nilai soal latihan siswa.

Setelah menghitung nilai normalitas dan hipotesis dari hasil perhitungan terbukti normal, maka data tersebut dapat diolah dengan uji statistik yaitu dengan uji-t pihak. Dari hasil perhitungan uji-t diperoleh nilai $t_{\text {hitu }}=$ 550,251 dan $t_{\text {tabel }}=550,251$ dan $t_{\text {tabel }}=$ 1,67022. Dengan demikian berrati $t_{\text {hitung }} \leq$ $t_{\text {tabel }}$ sehingga $H_{o}$ ditolak dan $H_{a}$ diterima.

Dari hal tersebut maka disimpulkan adanya pengaruh strategi pengaruh model pembelajaran berbasis masalah (PBM) terhadap hasil belajar siswa pada mata pelajaran IPS terpadu (Sejarah) kelas VIII di SMP Negeri 2 Palembang

\section{SIMPULAN}

Berdasarkan analis dan pembahasan mengenai pengaruh model pembelajaran berbasis masalah (PBM) terhadap hasil belajar siswa pada mata pelajaran IPS Terpadu (Sejarah) di kelas VIII SMP Negeri 2 Palembang. Hal ini dapat meningkatkan nilai rata-rata hasil belajar siswa, pada hasil tes akhir siswa. Berdasarkan hasil analisis tes menunjukan adanya pengaruh signitikan model pembelajaran berbasis masalah (PBM) terhadap hasil belajar siswa pada mata pelajaran IPS Terpadu (Sejarah) yang ditunjukan dengan koefisien $t_{\text {hit }}$ sebesar 550,25 atau lebih besar dari koefisien $t_{\text {tabel }}$ sebesar 1,67022 Rata-rata hasil tes siswa kelompok eksperimen atau yang dikenai perlakuan model pembelajaran berbasis masalah (PBM) pada mata pelajaran IPS Terpadu (Sejarah) lebih besar di bandingkan dengan Rata-rata hasil tes siswa kelompok eksperimen atau dikenai perlakuan pengaruh model pembelajaran berbasis masalah (PBM) pada mata pelajaran IPS Terpadu (Sejarah) lebih besar dengan nilai rata-rata hasil tes siswa kelompok kontrol dengan menggunakan metode cerama dan hasil tes, pada mata pelajaran IPS terpadu (Sejarah).

\section{DAFTAR PUSTAKA}

Arikunto, Suharsimi. 2002. Prosedur Penelitian Sutu Pendekatan Praktik. Jakarta: PT Rineka Cipta.

Jamil, Suprihatiningrum. 2017. Strategi Pembelajaran. Jogjakarta: Ar-Ruzz Media.

Rusman. 2010. Model-Model Pembelajaran. Jakarta: PT Raja Grafindo Persada

Slameto. 2010. Belajar dan Faktor yang Mempengaruhinya. Jakarta: Rineka Cipta.

Sutikno. 2010. Psikologi Belajar. Jakarta: Rineka Cipta.

Sugiyono. 2015. Metode Penelitian Tindakan Komperehensif. Bandung: Alfabeta.

Trianto. 2009. Mendesain Model InovatifProgresif. Jakarta: Prenada Media Group. 


\section{KETENTUAN PENULISAN ARTIKEL JURNAL KALPATARU}

1. Naskah berbahasa Indonesia yang disempurnakan bertemakan kesejarah yang meliputi hasil penelitian sejarah, pengajaran sejarah dan penelitian kebudayaan.

2. Naskah harus asli dan belum pernah dimuat dalam media lain. Naskah dapat berupa hasil penelitian/artikel kajian konseptual yang ditulis oleh perorangan dan atau kelompok.

3. Naskah ditulis dengan cara-cara yang sesuai dengan ketentuan penulisan artikel ilmiah menggunakan bahasa Indonesia yang baku, berupa ketikan, beserta soft file dalam CD-RW atau dengan mengirimkan email pada redaksi jurnal Kalpataru dengan alamat jurnalkalpatarusejarah@gmail.com, spasi tunggal, jenis huruf arial narrow ukuran 12, dengan panjang naskah antara 8-15 halaman pada kertas A4.

4. Artikel hasil penelitian memuat:

JUDUL

Nama Penulis

Abstrak

A. PENDAHULUAN

B. METODE PENELITIAN

C. HASIL DAN PEMBAHASAN

D. SIMPULAN

DAFTAR PUSTAKA
: XXX (HURUF KAPITAL)

: (disertai jabatan, institusi, dan email)

: (Bahasa Indonesia yang memuat 100-200 kata diikuti kata kunci, dengan jenis huruf arrial narrow dan ukuran huruf 11 serta dicetak miring).

: (memuat latar belakang masalah, tinjauan pustaka secara ringkas, masalah penelitian, dan tujuan penelitian).

5. Artikel Kajian Konseptual memuat:

JUDUL

Nama Penulis

Abstrak

PENDAHULUAN

Sub Judul

Simpulan

DAFTAR PUSTAKA
: (berisi simpulan).

: (berisi pustaka yang dirujuk dalam uraian naskah).

6. Referensi sumber dalam teks artikel ditulis dengan menggunakan side note, contoh (Jalaludin, 1991:79); sementara penulisan daftar pustaka disusun dengan ketentuan. Nama pengarang. Tahun terbit. Judul (dicetak miring). Kota terbit: Nama Penerbit. Contoh: Koentjaraningrat. 2010. Manusia dan Kebudayaan di Indonesia. Jakarta: Djambatan. Daftar pustaka hanya memuat pustaka/sumber yang dirujuk dalam uraian dan disusun menurut abjad tanpa nomor urut.

7. Naskah yang dimuat akan disunting kembali oleh redaksi tanpa mengubah isinya.

8. Naskah yang ditolak (tidak bisa dimuat) akan dikirim kembali ke penulis dengan pemberitahuan tertulis dari redaksi atau melalui email.

9. Penulis yang naskahnya dimuat akan mendapat 1 (satu) majalah nomor yang bersangkutan.

10.Kontak person: Muhamad Idris (081271498618); Eva Dina Chairunisa (082281267851); Jeki Sepriady (085269261780). 